\title{
Land Rights in International Human Rights Instruments: Appraising Nigeria's Compliance
}

\author{
Anugbum Onuoha \\ Faculty of Law, Rivers State University, Port Harcourt, Nigeria
}

\begin{abstract}
This article explores the scope and content of the right to property and critically evaluates the extent to which Nigeria's legal protection of private property rights is in conformity with international human rights instruments. It highlights the dimensional allegory that depicts the manifold complexes of regional and international human rights laws and provides clear understanding of the divergence in Nigeria's human rights adherence with specific focus on land and human rights preservation. It argues that the ostentatious narrative of human rights contains a connotation which portrays an epochal challenge set against the controversies of land policies flowing from tyranny of historical origin and the duplicities of the human rights scheme clouded and obscurity. The article advocates for the construction of a truly universal human rights corpus with regards to the protection of private lands in such manner that is multicultural, comprehensive, and intensely apolitical.
\end{abstract}

Keywords: Land, Human Rights, Laws, International Instruments.

DOI: $10.7176 / \mathrm{JLPG} / 99-07$

Publication date:July $31^{\text {st }} 2020$

\section{Introduction}

Land is one of the vital instruments of social security and the genesis of human rights. Land is not just the basement of most natural resources hence, human rights revolves round human beings whose very existence depend on land. Therefore, human access to land is courtesy to the exercise of the right to housing, right to water, right to health, and right to food.

The right to property is probably the oldest real right, much before concepts such as "right" or "real" (as opposed to "personal") were outlined. It has often been regarded as a "natural" right, derived from nature. Therefore, controversies on property are certainly as old as humanity itself. However, in the revolutionary period, the right to property was deemed a fundamental right and included as such in the charters approved at that time. This has continued up to our times, including in modern constitutions and international and regional human rights treaties. Its rationale is mostly to protect the right to property against governmental action, even though there are opposite policy preferences as to regulation of property rights at the domestic level.

The right to property is probably the oldest real right, much before concepts such as "right" or "real" (as opposed to "personal") were outlined. It has often been regarded as a "natural" right, derived from nature. Therefore, controversies on property are certainly as old as humanity itself. However, in the revolutionary period, the right to property was deemed a fundamental right and included as such in the charters approved at that time. This has continued up to our times, including in modern constitutions and international and regional human rights treaties. Its rationale is mostly to protect the right to property against governmental action, even though there are opposite policy preferences as to regulation of property rights at the domestic level. ${ }^{1}$

The right to property first came within the ambit of the human rights laws during the French Revolution's Déclaration des droits de l'Homme et du citoyen ${ }^{2}$ and the United States Bill of Rights which encompasses the first ten amendments to the United States Constitution. ${ }^{3}$ Ever since the $18^{\text {th }}$ Century, there has been slow but steady development with regards to classifying the rights to land as human rights. Of recent the emphasis have shifted to forceful eviction and women rights to land. ${ }^{4}$

Forced eviction is the perpetual or momentary removal of a person or a group of persons from their lands against their willingness to be moved..$^{5}$ The use of the coercive apparatuses ${ }^{1}$ of the state to remove legitimate

\footnotetext{
${ }^{1}$ Sayın, Yiğit and Lehavi, Amnon and Oder, Bertil and Onok, Murat and Francavilla, Domenico and Torre de Silva, Victor and Sudarshan, R., Land Law and Limits on the Right to Property: Historical, Comparative and International Analysis - LSGL Human Rights Group Paper (May 23, 2017). DOI: 10.1515/eplj-2017-0002; Law Schools Global League (LSGL) Research Paper No. 5. Available at SSRN: https://ssrn.com/abstract=2972489 accessed 22 April 2020

${ }^{2}$ This was a declaration of 1789

${ }^{3}$ Enacted September 25, 1789 and ratified on 15 December 1791

${ }^{4}$ United Nations. Transforming Our World: the 2030 Agenda for Sustainable Development. Washington, D.C.: United Nations, 2016.

${ }^{5}$ World Resources Institute (WRI). Climate benefits, tenure costs. The economic case for securing indigenous rights in the Amazon.
} 
land owners and occupiers from their property in permitted under national laws of various countries in contrary to international human rights laws. Wickeri and Kalhan ${ }^{2}$ observed that:

Without secure land rights, individuals and communities live under the constant threat of eviction, impacting a range of fundamental human rights. Tenure security in land or secure usage rights in land, in the form of formal legal, customary or religious rights, can provide more predictability and secure access to fundamental rights, including to food, housing, water, and health. The right to housing and the prohibition against forced evictions, both of which relate to land access, have been defined in numerous international documents, but the right to land, and the broader implications of access to land in the international human rights framework, remains imprecise. ${ }^{3}$

In almost every country of the world, in accordance with international laws, the right to private property is assumed to have a straight positive effect on the human person's necessity and capability to provide for his or her existence through various activities. ${ }^{4}$ It is against this background that this scholarly paper seeks to explore the aspects of the national, regional and international instruments that portrays the multifarious ${ }^{5}$ developments of human rights laws with respect to the right to property and provides thoughtfulness of the departure in Nigeria's human rights observance with precise emphasis on land and human rights preservation. In furtherance of that core objective, it is crucial to explore the international law angle with which to provide the insightful appraisal of the compliance mechanism of Nigeria legal frameworks.

\section{Literature Review}

Gilbert ${ }^{6}$ explored the interrelationships between land and human rights and observed that "the right to property is a common denominator throughout most of the legal systems of the world, which usually frame it as one of the fundamental liberties of the individual." Similarly, he highlighted that the warranty of "property rights in land was one of the central issues that triggered the development of an emergent human rights system." Nonetheless, land rights are routinely becoming the dominant piece of the avowal of personal freedoms against national governments in several developed countries. ${ }^{7}$

Gilbert $^{8}$ went further to argue that the right to property was one of the issues that led to the clamour for the elimination of discrimination against women which culminated in the formulation of the United Nations Convention on the Elimination of All Forms of Discrimination against Women (CEDAW). ${ }^{9}$ He asserted that the particular right to property is the base-rock of article 16 of CEDAW which obligates States to safeguard "[T]he same rights for both spouses in respect of the ownership, acquisition, management, administration, enjoyment and disposition of property, whether free of charge or for a valuable consideration." The discriminatory practices of many of the ethnic units of Nigeria hurts women and the girl child with regards to land rights and inheritance.

Washington, D.C.: WRI, 2016

${ }^{1}$ J. F Hart. Property Rights, Costs, and Welfare: Delaware Water Mill Legislation, volume 27, p. 456 - 61

${ }^{2}$ Wickeri, Elisabeth and Kalhan, Anil, Land Rights Issues in International Human Rights Law. Malaysian Journal on Human Rights, Vol. 4, No. 10, 2010; Drexel University Earle Mack School of Law Research Paper; Fordham Law Legal Studies Research Paper No. 1921447. Available at SSRN: https://ssrn.com/abstract=1921447

${ }^{3}$ According to the Centre on Human Rights in Conflict of the Minority Rights Group International, Published by the University of East London, England, titled: Moving Towards A Right To Land: The Committee On Economic, Social and Cultural Rights' Treatment Of Land Rights As Human Rights;....explains as follows: "In many countries, land rights and security of tenure constitute the basis for access to food, livelihoods, housing and development for a large percentage of the population, and are an important source of national food security. Without access to land, many people find themselves in a situation of great economic insecurity. Access and rights over lands are also frequently stratified on a hierarchical and segregated system where the poorest, least educated, and otherwise disadvantaged do not hold security of land tenure," Online at: Website www.minorityrights.org accessed 2 April 2020

${ }^{4}$ Rights and Resource Initiative (RRI). Recognizing Indigenous and Community Rights. Priority steps to advance development and mitigate climate change. Washington, D.C.: RRI, 2014.

${ }^{5}$ Gregory S. Alexander. Ownership and Obligations: The Human Flourishing Theory of Property (October 31, 2013). 43 Hong Kong L.J. 451 (2013); Cornell Legal Studies Research Paper No. 13-93. Available at SSRN: https://ssrn.com/abstract=2348202 accessed 22 April 2020

${ }^{6}$ Gilbert, Jeremie, Land Rights as Human Rights: The Case for a Specific Right to Land (February 1, 2013). SUR International Journal on Human Rights, v. 10, n. 18, Jun. 2013. Available at

SSRN: https://ssrn.com/abstract=2401190 or http://dx.doi.org/10.2139/ssrn.2401190

${ }^{7}$ Bart J Wilson. The Meaning of Property in Things (November 3, 2019). 'The Property Species: Mine, Yours, and the Human Mind,' Oxford University Press, July, 2020, Forthcoming. Available at

SSRN: https://ssrn.com/abstract=2867734 or http://dx.doi.org/10.2139/ssrn.2867734

${ }^{8}$ Ibid

${ }^{9}$ The Convention on the Elimination of All Forms of Discrimination against Women (CEDAW), adopted in 1979 by the UN General Assembly, is often described as an international bill of rights for women. Consisting of a preamble and 30 articles, it defines what constitutes discrimination against women and sets up an agenda for national action to end such discrimination adapted from https://www.un.org/womenwatch/daw/cedaw/ accessed 20 April 2020 
For instance, in Ukeje v. Ukeje, ${ }^{I}$ the Supreme Court of Nigeria held that the deprivation of the right to property inheritance on the grounds of sex was contrary to law therefore null and void. The court also stated that it was contrary to Section 42(2) of the Constitution of the Federal Republic of Nigeria which provides inter alia: "No citizen of Nigeria shall be subjected to any disability or deprivation merely by reason of the circumstances of his birth."

Gilbert $^{2}$ expressed concern as to the lack of seriousness by the international community to emphatically push the right to property into the forefront of international law. Accordingly he observed that "despite these mentions of the right to property, the main international human rights treaties do not integrate a specific mention of land property rights" Therefore,

When property rights have been integrated, it is mainly in the context of non-discrimination (ICERD and CEDAW). Ultimately, property rights are only strongly affirmed in the UDHR, and the connection to land rights in this context remains tenuous since it was not originally envisaged.

Gilbert $^{3}$ concluded his treatise by advocating for the absorption of the rights to land as human rights in the relevant international treaties. Heard ${ }^{4}$ posited that several contending pedestals have been avowed for universal human rights. Therefore, that it is indispensable to apprehend the numerous basics, since they do result in reasonably dissimilar indulgences of the specific paybacks safeguarded by human rights. Gilbert ${ }^{5}$ concluded that "each approach to human rights has different strengths and vulnerabilities in facing the challenges posed by relativism and utilitarianism."

Vestaliza ${ }^{6}$ conducted an investigative analysis of the relevance of the principles of human rights to realistic human habitations and observed that the application and fortification of the universal human rights is generally complicated and difficult to put in practice. ${ }^{7}$ Therefore that:

The idea of universal human rights has been challenged by cultural relativists, on the basis that the claim to universal applicability reflects a form of cultural imperialism or hegemony. ${ }^{8}$ Relativists hold that the universal human rights discourse originates from Western philosophical positions which conceptualise the individual as the fundamental political actor, rather than the collective or communal units privileged in many non-Western traditions. ${ }^{9}$ Human rights discourses can only make universalist claims, argue cultural relativists, because of the global political ascendency of the West. ${ }^{10}$ In response, universalists accuse relativists of allowing politically and socially repressive practices, which subordinate individual wellbeing to collective utility, to be justified and legitimised on the basis of cultural difference.

\section{The Rights to Property in International Law and Regional Laws}

A linear methodology to sustenance of international human rights mechanisms that pronounced the right to property often begins with the Universal Declaration of Human Rights (UDHR) ${ }^{11} 1948$. For instance, Article 17 of the Convention stipulates that: "Everyone has the right to own property alone as well as in association with others. No one shall be arbitrarily deprived of his property." According to Cheneval, ${ }^{12}$ the chronological progress of the awareness of human rights is closely associated to the right to private (individual or common) ${ }^{13}$ property, especially of indigenous peoples. Wollstonecraft, ${ }^{14}$ observed that: "Nature authorizes and reason

\footnotetext{
${ }^{1}$ SC. 224/2004; (2014) LPELR-22724(SC); (2014) 11 N.W.L.R (PART 1418) P. 384

2 [n. 10]

3 ibid

${ }^{4}$ Andrew Heard, Human Rights: Chimeras In Sheep's Clothing? (1997) online at: https://www.sfu.ca/ aheard/intro.html accessed 24 April 2020

5 ibid

${ }^{6}$ Aulia Octa Vestaliza. The Cultural Relativist Critique of Human Rights: Politics and problems.

Online at: https://www.academia.edu/ accessed 29 April 2020

${ }^{7}$ ibid

${ }^{8}$ Fernando Teson, 'International Human Rights and Cultural Relativism', Va. J. Intl. 25 (1984), 869.

${ }^{9}$ Lynda Bell et al (eds.), Negotiating Culture and Human Rights (New York: Columbia University Press, 2001 ), 285.

${ }^{10}$ Jack Donnelly, 'The Relative Universality of Human Rights', Human Rights Quarterly, 29/2 (2007), 285.

${ }^{11}$ The United Nations General Assembly in Paris on 10 December 1948 (General Assembly resolution 217 A) as a common standard of achievements for all peoples and all nations. It sets out, for the first time, fundamental human rights to be universally protected and it has been translated into over 500 languages (see: https://www.un.org/en/universal-declaration-human-rights/ accessed 12 April 2020)

${ }^{12}$ Francis Cheneval Property Rights as Human Rights online at: http://www.philosophie.uzh.ch/static/SHRB/PDFs/Kap 1.pdf accessed 21 April 2020

${ }^{13}$ Georg Cavallar, "The Rights of Strangers. Theories of International Hospitality, the Global Community, and Political Justice since Vitoria," Aldershot 2002.

${ }^{14}$ Mary Wollstonecraft, “A Vindication of the Rights of Men [1790],” Oxford 1993, p. 23.
} 
sanctions ... the right a man has to enjoy the acquisitions which his talents and industry have acquired; and to bequeath them to whom he chooses."

The right to property relates to private entities, individual and communal form of ownerships ${ }^{1}$ however, the UNDHR did emphasize on the absolute nature of the rights to property hence, the right can be derogated in circumstances where it is necessary to forestall public interest and public policies though, while such derogative power is applied, it is obligatory to avoid illogical, arbitrary and reckless behaviour. ${ }^{2}$ Despite the prominence of Article 17 of the UNDHR, the right to property as human rights is not included in other international instruments such as the International Covenant on Civil and Political Rights (ICCPR) 1966 and the International Covenant of Economic, Social and Cultural Rights (ICESCR) 1966.

Nonetheless, the International Labour Organization Convention No. 169 concerning Indigenous and Tribal Peoples identifies the rights of proprietorship and ownership of the peoples concerned over private and communal properties is recognised thus, the obligations of the State parties to recognise such rights and safeguard same, is stipulated in Article 14 of the Instrument. ${ }^{3}$

The African Charter on Human and Peoples' Rights (ACHPR) provides in Article 14, inter alia: "The right to property shall be guaranteed. It may only be encroached upon in the interest of public need or in the general interest of the community and in accordance with the provisions of appropriate laws." Similarly, article 13 of the ACHPR acknowledges property rights and stipulates that, every citizen has "the right of access to public property and services in strict equality of all persons before the law." Additionally, article 21 of the ACHPR identifies the right of all peoples to freely dispose of their wealth and natural resources and that the right shall be exercised in the exclusive interest of the people, who may not be deprived of same. ${ }^{4}$

In the United States, article 21(1) of the American Convention on Human Rights provides that: "Everyone has the right to the use and enjoyment of his property. The law may subordinate such use and enjoyment to the interest of society." Article 21(2) provides inter alia: "No one shall be deprived of his property except upon payment of just compensation, for reasons of public utility or social interest, and in the cases and according to the forms established by law." 5

The International Convention on the Elimination of All Forms of Racial Discrimination was adopted by the United Nations in 1965. Article 5(v) acknowledges "the right to own property alone as well as in association with others" therefore, obligates State parties to establish the machinery for the elimination of all forms of racial discrimination and to preserve human dignity with regards to land rights. Similarly, Articles 5(3) and Article 30(3) of the Convention on the Rights of Persons with Disabilities emphatically states that private property rights must be preserved and guaranteed by State parties.

Article 14 of the International Labour Organization Convention No. $169^{6}$ regarding Indigenous and Tribal Peoples identifies the rights of tenure and control of the global indigenous peoples' rights to their heritage ${ }^{7}$ of $^{2}$ land hence, it mandates the State parties to ascertain and recognise such lands and provide effective safeguards for the protection of the rights of title and proprietorship thereof. ${ }^{8}$ Article 2(1) of the ICCPR, provides as follows:

Each State Party to the present Covenant undertakes to respect and to ensure to all individuals within its territory and subject to its jurisdiction the rights recognized in the present Covenant, without distinction of any kind, such as race, colour, sex, language, religion, political or other opinion, national or social origin, property, birth or other status.

Article 2(2) of the International Covenant on Economic, Social and Cultural Rights (ICESCR) states inter alia:

The States Parties to the present Covenant undertake to guarantee that the rights enunciated in the present Covenant will be exercised without discrimination of any kind as to race, colour, sex, language, religion, political or other opinion, national or social origin, property, birth or other status.

\footnotetext{
${ }^{1}$ Eric T. Freyfogle. Property and Liberty (March 1, 2010). Harvard Environmental Law Review 34:1 (2010), 75-118. Available at SSRN: https://ssrn.com/abstract=1024574 or http://dx.doi.org/10.2139/ssrn.1024574 accessed 20 April 2020

${ }^{2}$ International Work Group for Indigenous Affairs (IWGIA). The Indigenous World 2017. Copenhagen: IWGIA, 2017.

${ }^{3}$ International Land Coalition (ILC). Indigenous peoples' rights to land, territories and resources. By Birgitte Feiring. Rome: ILC, 2013.

${ }^{4}$ Article 21 further state that "in case of spoliation the dispossessed people shall have the right to the lawful recovery of its property as well as to adequate compensation".

${ }^{5}$ R Ellen; P. Parkes, \& A. Biker (ed.). Indigenous Environmental Knowledge and Its Transformation, critical anthropological perspectives. Singapore: Harwood Academic Publishers, 2000

${ }^{6}$ Adopted in 1989

${ }^{7}$ Christophe Golay and Cismas, Ioana, Legal Opinion: The Right to Property from a Human Rights Perspective (2010). Available at: SSRN: https://ssrn.com/abstract=1635359 or http://dx.doi.org/10.2139/ssrn.1635359 accessed 20 April 2020

${ }^{8}$ Green Climate Fund. 2018. GCF Indigenous Peoples Policy. GCF/B.19/05. GCF Meeting of the Board, 27 February - 1 March 2018. Songdo, Incheon, Republic of Korea. Provisional agenda item 17.
} 
Despite the international instruments recognising private and group property rights as human right, ${ }^{1}$ on the regional level, there has been attempts to streamline regional laws alongside the international laws. ${ }^{2}$ For example, Article 1 of the first Protocol the European Convention on Human Rights (ECHR), of 1952, states:

Every natural or legal person is entitled to the peaceful enjoyment of his possessions. No one shall be deprived of his possessions except in the public interest and subject to the conditions provided for by law and by the general principles of international law.

By the same token, the African Charter on Human and Peoples' Rights ${ }^{3}$ recognise the right to property however, it permits States to derogate and infringe on the rights on the grounds of public interest. The infringement on the right to property should therefore conform to the relevant extant laws of the particular State. ${ }^{4}$

\section{The Effects Of The Land Use Act On Human Rights In Nigeria}

By the authority of section 43 of the Constitution of the Federal Republic of Nigeria ${ }^{5}$ the right to acquire private property is a constitutional right hence, it provides that: "subject to the provisions of this Constitution, every citizen of Nigeria shall have the right to acquire and own immovable property anywhere in Nigeria." Although, section 44(1) stresses that:

No moveable property or any interest in an immovable property shall be taken possession of compulsorily and no right over or interest in any such property shall be acquired compulsorily in any part of Nigeria except in the manner and for the purposes prescribed by a law that, among other things:- (a) requires the prompt payment of compensation therefore and (b) gives to any person claiming such compensation a right of access for the determination of his interest in the property and the amount of compensation to a court of law or tribunal or body having jurisdiction in that part of Nigeria.

This constitutional provision are not particularly classified in the constitution as human right. Nonetheless, the main legislation that governs land and the accompanying rights in Nigeria is the Land Use Act, 1978 which pre-existed the enactment of the said constitution therefore, to give retrospective effect to the Land Use Act, ${ }^{6}$ section section 315(5)(d) of the 1999 Constitution (as amended) identifies and gives effect the Land Use Decree which was later re-enacted in its entirety as Land Use Act 1978 (LUA). ${ }^{7}$

Section 1 of the LUA places the lands of the States of Nigeria in the hands of the Governors. ${ }^{8}$ Therefore, it inescapably created a trust of land in each state of Nigeria ${ }^{9}$ with Governors as the trustees of every land in each State. Consequently, LUA changed the customary land tenure system of the tribes in the Nigeria. The shift of land ownership rights "was explained in Nkwocha $v$ Governor of Anambra State ${ }^{10}$ that, section 1 of the LUA infers that it is illegal for any private individual to proclaim outright rights over lands in Nigeria." 11 In Yakubu $v$. Abioye ${ }^{12}$ and Savannah Bank v. Ajilo ${ }^{13}$ the Supreme Court said: “... with the promulgation of the LUA 1978 all the unlimited rights and interest Nigerians had in their lands were swept away and substituted with very limited right and rigid control of the use of their limited right by military Governors and local government."14

The provision of section 21 of the LUA makes clear that no property 'owner' is permitted to transfer, alienated, assign, mortgage, sub-lease or otherwise of any rural land in Nigeria "without the approval of the appropriate Local Government." By the same token, section 22 forbids anyone to alienated, assign, mortgage, transfer, sublease or otherwise of any urban land in Nigeria without the first obtaining the consent of the Governor of the State where the land is situated. In the same direction, section 26 forbids the any land dealings

\footnotetext{
${ }^{1}$ S. Enemark, L. T Hvingel \& D. Galland. Land administration, planning and human rights. Planning Theory, 13(4), 331-348. (2014) DOI: $10.1177 / 1473095213517882$

${ }^{2}$ Food and Agriculture Organization (FAO). Policy on Indigenous and Tribal Peoples. Rome: FAO, 2010.

${ }^{3}$ AfCHPR

${ }^{4}$ United Nations collaborative programme on Reducing Emissions from Deforestation and forest Degradation (UN-REDD). Guidelines on Free, Prior and Informed Consent (FPIC). Geneva: UN-REDD, 2013.

51999 (as amended)

${ }^{6}$ Cap L5 Laws of the Federation of Nigeria 2004

${ }^{7}$ Onuoha, Anugbum, The Effects of Customary Right Of Occupancy on Indigenous Land Use of the Ikwerre People of Nigeria. Humberside Journal of Law and Social Sciences, Volume 10(1) 2020 pp. 26 - 42

${ }^{8}$ Adisa v Oyinwola (2000) 10 NWLR 116

${ }^{9}$ Obikoya \& Sons Ltd v Governor of Lagos State \& Anor (1987) 1 NWLR (Pt 50) 385; Nitel v Ogunbiyi (1992) 7 NWLR (Pt 255) 543; Also in Majiyagbe v AG Northern Nigeria (1957) NNLR

${ }^{10}(1984) 6$ SC p. 362

11 [n. 45] 33

12 (1991) 5 NWLR (Pt. 100) p.130

13 (1989) I NWLR (Pt. 57) pg. 305 at 421

${ }^{14}$ Kachalla v. Banki (2006) All FWLR (Pt. 309) p. 1420; Ezennah v. Attah (2004) All FWLR (Pt. 202) p. 1858 at 1884
} 
such as assignment, mortgage, transfer of possession, sublease or otherwise without the governor's consent as stated in the case of Savannah Bank (Nig) Ltd vs. Ajilo, ${ }^{1}$ where it was held that:

Having considered the Act as a whole, ... bound by the case of Nahman

v. Odutola ${ }^{2}$ and also Supreme Court decisions in the case of Labaran

Nakyauta $v$. Ibrahim Maikima ${ }^{3} \ldots$ that failure to obtain the required consent of the ... Governor under Section 22 of the Act has rendered the deed of mortgage Exhibit A null and void ab initio and the mortgage transaction illegal. Accordingly, the power of sale under the mortgage cannot be exercised. ${ }^{4}$

The effects of the consent provision of the LUA is that there is limited rights to property for private persons. The right to property is supposed to be unhindered. This provision infringes on several international human rights instruments.

By the authority of section 5 of the LUA, each State Governor in Nigeria has the power to grant statutory right of occupancy to suitably qualified applicants. Furthermore, section 6 authorizes the local government councils to grant customary right of occupancy on lands located in the rural areas of Nigeria where the council is satisfied that the applicants seek to reside on same or to use it for farming. The human rights implications of section 5 and section 6 is that the Governor and/or the local government council may wish to deny issuance of the required certificate(s) thereby frustrate the land owners of the full utilization of the property. Notwithstanding, the provision contained in section 6(2) that: "No single customary right of occupancy shall be granted in respect of an area of land in excess of 500 hectares if granted for agricultural purposes, or 5,000 hectares if granted for grazing purposes, except with the consent of the Governor." Section 6(3) authorizes the "local government to enter upon, use and occupy for public purposes any land within the area of its jurisdiction."

Section 34(2) provides inter alia: "Where the land is developed, the land shall continue to be held by the person in whom it was vested immediately before the commencement of this Act as if the holder of the land was the holder of a statutory right of occupancy issued by the Governor under this Act." These provision of the LUA constitutes a deprivation of access to property of private and communal lands which does not conform to article 17 of the UNDHR which specifically stipulates that: "Everyone has the right to own property alone as well as in association with others. No one shall be arbitrarily deprived of his property."

It is important to highlight that most of the rural lands in Nigeria are historically linked to indigenous people and, that indigenous people are protected under international law hence, Article 8(1) of the United Nations Declaration on the Rights of Indigenous Peoples, states that: "Indigenous peoples and individuals have the right not to be subjected to forced assimilation or destruction of their culture." Therefore that:

States shall provide effective mechanisms for prevention of, and redress for: (a) Any action which has the aim or effect of depriving them of their integrity as distinct peoples, or of their cultural values or ethnic identities; (b) Any action which has the aim or effect of dispossessing them of their lands, territories or resources; (c) Any form of forced population transfer which has the aim or effect of violating or undermining any of their rights ...

A critical look at the powers of the Governors in Nigeria to revoke private citizen's rights to property and effect compulsory takings from the angle human rights cannot be fully explored without a full understanding of the implications of international law. According to Nyarko, ${ }^{5}$

$\ldots$ the exact frontiers of the right to property remain quite uncharted at the global level the vacuum has been filled by the regional human rights systems and soft law [in Nigeria] the Constitutional protection of the right to property and quite elaborate rules to be followed during compulsory acquisition have not translated into revision of the

\footnotetext{
1 (1989) I NWLR (pt 97) 805

2 (1953) 14 WACA $381 @ 384$

3 (1975) LCN/01442(SC).

${ }^{4}$ The decision of the court in Savanah Bank v. Ajilo was improved in Awojugbagbe Light Industries Ltd vs. Chinukwe \& ANOR, where the court stated that: "The mere fact that the Deed of Mortgage was executed in 1980 or 1982 and the Governor's consent was obtained in 1985 does not affect the validity of the Deed. Before the Governor's consent it was a lawful agreement to mortgage which could be enforced." Therefore that: "As can be seen from the issues formulated, the main issue was whether the deed of mortgage was in fact executed in 1980 before the governor's consent in 1985. In which case the Mortgage will be caught by the provisions of Section 22 of the Land Use Act which stipulates that the prior consent of the Governor must be sought and obtained before the deed of mortgage is executed ... and contended that this of course was not what the Act stated. No where did the Act state that consent must be given before execution of any document contrary, sections 22(2) and 26 presupposed the existence of an agreement before the Governor's consent."

${ }^{5}$ Michael Gyan Nyarko. The Right to Property and Compulsory Land Acquisition in Ghana: A Human Rights Perspective. African Journal of International and Comparative Law Volume 27, Issue 1 February, 2019
} 
compulsory acquisition laws, which remain largely incoherent and inconsistent with the requirements of the Constitution and international human rights law. ${ }^{1}$

In accordance with section 28(1) of the Land Use Act, "It shall be lawful for the Governor to revoke a right of occupancy for overriding public interest." Accordingly, any such revocation should be effected where there is the need to do so for overriding public interest. ${ }^{2}$ It is against this background that Paul ${ }^{3}$ contended that:

The power of eminent domain may seem innocuous to some, but its use can cause serious psychological and economic damage to property owners. Perhaps, the reason that most citizens unaffected by its use find it non-controversial is that for most of its history it was used in a very limited way. Few people would quibble over a power to provide land for post offices or even highways. Today, however, its reach has been greatly extended, and many landowners have been severely affected.

It is observed that the conflicts between human rights to property and the power of the State to forcefully take such lands are not only peculiar to Nigeria. For example, In Sifuna's ${ }^{4}$ study of Kenya, explains inter alia: ... the exercise of eminent powers is still largely fashioned along the draconian approach of the colonial regime. It is draconian and undemocratic in that it fails to recognize the landowner's right of dissent, which is an integral part of the freedom of conscience enshrined in the Bill of Rights. The process is devoid of considerations of human values and principles of good governance such as negotiation, consultation, livelihood, and human rights. The state retains an upper hand as apparently all that it is required to do is put the owner on notice, thereafter his views are irrelevant.

However, in Dantsoho v. Mohammed, ${ }^{5}$ it was held that, on no circumstance should the Governor compulsorily acquire any private property for his personal use or for re-assignment to another private entity. Even though the LUA provides that the party to which the revocation was served upon should be compensated, section 47(2) of the LUA states: "No court shall have jurisdiction to inquire into any question concerning or pertaining to the amount or adequacy of any compensation paid or to be paid under this Act." By the same token, section 47(1) provides as follows: "Act shall have effect notwithstanding anything to the contrary in any law or rule of law including the Constitution of the Federation or of a State and, without prejudice to the generality of the foregoing, no court shall have jurisdiction to inquire into: (a) Any question concerning or pertaining to the vesting of all land in the Governor in accordance with the provisions of this Act: or (b) Any question concerning or pertaining to the right of the Military Governor to grant a statutory right of occupancy in accordance with the provisions of this Act; or (c) any question concerning or pertaining to the right of a Local Government to grant a customary right of occupancy under this Act." It is contended that section 47 of the LUA is contrary Article 17 of the UNDHR.

\section{Conclusion}

According to Mchangama, ${ }^{6}$ the orthodox thought of the right to property predominantly involves the adverse obligation that shields against capricious expropriation and rule of private property. Therefore, the scope of the classical indulgence of the right to property comprises affirmative obligations, to such extent that it is restricted to the adoption of the suitable legal measures for the protection of private persons against the transgressions of third parties.

Unfortunately, "the right to property provides opportunities and agency, but it does not guarantee results." "7 This is because the right to property fails to include mandatory obligations to compel the government of nations to fully safeguard the right to property. Such a human rights obligation would make the protective sphere of the right to property largely illusory and would undermine, rather than strengthen, human dignity. Moreover, a

${ }^{1}$ Ibid, at p. 1 (the addition of Nigeria replaces Ghana from the original source article)

${ }^{2}$ Section 28(2) of the Act defines overriding public interest as: "(a) the alienation by the occupier by assignment, mortgage, transfer of possession, sublease, or otherwise of any right of occupancy or part thereof contrary to the provisions of this Act or of any regulations made thereunder; (b) the requirement of the land by the Government of the State or by a Local Government in the State, in either case for public purposes within the State, or the requirement of the land by the Government of the Federation for public purposes of the Federation; (c) the requirement of the land for mining purposes or oil pipelines or for any purpose connected therewith." Furthermore, the overriding public interest .... "Including but not limited to the purpose of exclusive government use; development for public good; and on the grounds of preservation of public safety."

${ }^{3}$ Ellen Frankel Paul, Property Rights and Eminent Domain (Transaction Publishers 2008)

${ }^{4}$ Nixon Sifuna, 'Using Eminent Domain Powers to Acquire Private Lands for Protected Area Wildlife Conservation: A Survey under Kenyan Law'2/1 Law, Environment and Development Journal 2006, p. 84, available online at: http://www.lead-journal.org/content/06084.pdf $\geq$ accessed on 8 May 2020

${ }^{5}$ (2003) 6 NWLR (Pt.817)457 2 (2003) 2 S.C 42 3; also in Foreign Finance v. L.S.D.P.C [1991] 4N.WL.R. (Pt. 184) p. 157

${ }^{6}$ Jacob Mchangama. The Right to Property in Global Human Rights Law. Cato Institute Policy Report. May/June 2011. Online at: https://www.cato.org/policy-report/mayjune-2011/right-property-global-human-rights-law accessed 10 May 2020 7 Ibid 
positive duty to fulfill the right to property would make the application of this right wholly arbitrary and incompatible with the requirements of legal clarity and foreseeabilty on which respect for the rule of law depends."

From all indications and a careful evaluation of the international legal instruments, the legal frameworks for the classification of the right to property as human right is problematic. In all every country, the right to property appears to be restricted to personal property and very weak when it comes to lands. For example, Article 8 of the European Convention on Human Rights protect the individuals' right to private and family life but silent on the safeguard of lands. Similarly, Articles 14 and 21 of the African Charter on Human and Peoples' Rights provides for the right to property however, it permits the rights to be derogated for the interest of public need or in the general interest of the community and in accordance with the provisions of appropriate domestic laws. It is therefore recommended that a truly universal human right instrument that protects the right to real property of private entities should be created at international and national levels without the inclusion of derogative clauses. 